\title{
Community-Based Ecotourism Management: The Case of a Cooperative in Mazatlán, Sinaloa, Mexico
}

\author{
Jorge Ramos-García ${ }^{1 *} /$ Juan Pedro Ibarra-Michel ${ }^{2^{*}}$ / Mónica Velarde-Valdez ${ }^{1}$ \\ e-mail: jorgeluisrg@outlook.com, juanpedroibarra.udo@gmail.com, mvelardemx@yahoo.com \\ 1 Department of Economic and Administrative Sciences, Universidad de Occidente, Sinaloa, Mexico \\ ${ }^{2}$ Department of Social Sciences and Humanities, Universidad de Occidente, Sinaloa, Mexico
}

Ramos-García J., Ibarra-Michel J. P., \& Velarde-Valdez M. (2017). Community-Based Ecotourism Management: The Case of a Cooperative in Mazatlán, Sinaloa, Mexico. Czech Journal of Tourism, 6(2), 155-170. DOI: 10.1515/cjot-2017-0008.

\begin{abstract}
Nature-based ecotourism has been a growing trend, especially in rural areas where balance with the environment is desirable and it turns into a driver for economic and social development. An ecotourism cooperative operating in the "El Verde Camacho" Sanctuary, is an example of collaborative work between the government experts and the community. The cooperative was created with the support of the National Commission of Natural Protected Areas (CONANP, in Spanish Comisión Nacional de Áreas Naturales Protegidas), developed and funded by this government office, it involved the advice of experts in ecology as well as cooperative's management and residents of "El Recreo" community. This study aims to describe the involvement process and community management as well as the benefits derived from ecotourism according to the reviewed literature; a case study with a qualitative approach was defined in the Sanctuary in this regard. Semi-structured interviews were used to discover community members' perception of management involvement and benefits of ecotourism. The findings show positive opinions of community residents.
\end{abstract}

\section{Keywords}

ecotourism, management, rural cooperative, community

JEL classification: L83, Q56, J54

* These authors collaborated equally to this work. 


\section{Introduction}

Ecotourism has been internationally managed from a perspective that is derived from the model of sustainable tourism development, which involves social, economic and environmental dimensions. The academic literature of ecotourism is managed from two areas: the first is a theoretical perspective, giving the concept benefits both positive and adverse, but specifically referring to the benefits of its theoretical construction. The second perspective is part of the operation of ecotourism where authors like Brenner and San German (2012) mentioned that there was a gap between theoretical knowledge of ecotourism and the operationalization of the concept in actual practice. However, the trend analysis today is to present case studies where practical experience collected in communities explains the development of ecotourism activities (Weaver \& Lawton, 2007).

More recently, geotourism has emerged, being described among others by Dowling (2013). He perceives this relatively new sustainable tourism form as an enrichment of ecotourism by adding the geological and the landscape aspects to its scope, as well as by fostering its mission to contribute to sustainable development of the area. This point of view can be very useful to describe all the implications of human intervention in natural areas intended to promote tourist activities.

This work took place in the community of El Recreo located a few miles from an important tourist destination, Mazatlán México. A case study with a qualitative approach was carried out at the ecotourism cooperative "Servitur Rural El Verde Camacho" in the sea turtle Sanctuary managed by government institutions and with the assistance of members of the community.

The main research question of this investigation is:

How was the process of involvement and community management of "El Recreo" residents in ecotourism activities at the "El Verde Camacho" sanctuary performed?

The secondary question is as follows:

What are the perceived benefits of ecotourism for the residents of "El Recreo" community?

Therefore, the aim of this study is to describe the process of involvement and benefits of ecotourism in the community of "El Recreo". This work is based on some of the premises proposed for this tourist activity by some authors like Ross and Wall (1999), who see in ecotourism the need for conservation of the natural environment and the support to achieve local community's aspirations; Stronza and Gordillo (2008) handle non-economic benefits such as the development of negotiation skills and people management, Blamey (2001) mentions that the results expected from ecotourism operation should be the support of the local economy and the conservation of the natural and social environment. Wood (2002, p. 10) also identifies some components of ecotourism as the redirection of local participation, ownership, and business opportunities, particularly for the rural people. Finally, the proposal of Dowling (2013) is considered due to 
the characteristics of the tourist activities taking place in the studied community that are related to the description of geotourism as stated by the author.

As a primary research hypothesis, it was considered that the involvement degree of the community would determine the success of ecotourism activities as far as their perception of the benefits come clear and tangible.

The study results reflect the importance of governmental organizations for the development of ecotourism practice involving the participation of community residents. This study also emphasizes the description of the cooperative's members perception about the benefits of ecotourism in their community, the environment and about themselves.

\section{Theoretical basis}

\section{From Ecotourism to Geotourism}

Ecotourism as a concept has been defined in a form of sustainable tourism or naturebased tourism, where it shares some principles such as education and interpretation of the natural environment (Blamey, 2001; Wood, 2002), as well as it contributes to the conservation of the natural resource and encourage social development (Tsaur, Lin, \& Lin, 2006). According to Wood (2002), eco-tourism should be a support tool for sustainable development in communities that are primarily rich in natural elements, without excluding the socio-cultural and economic factors related to the development of sustainable tourism (Wood, 2002).

The first conceptual references of the term ecotourism are with Hetzer (1965, p. 5) who identifies four pillars or principles of responsible tourism: "1) minimizing environmental impacts, 2) respecting local cultures, 3) maximizing the benefits for local people and, 4) maximizing tourist satisfaction".

The central premise of eco-tourism is to optimally maintain natural resources (flora and fauna) through proper use that allows communities to generate economic gains as an incentive to the conservation and displacement of destructive activities, such as the extraction of flora and fauna (Kiss, 2004; Boyd \& Butler, 1996).

Other authors like Stronza and Gordillo (2008, p. 449) mentioned that residents of tourist sites pay the costs associated with conventional forms of tourism. In contrast, ecotourism is designated as a tool that provides direct benefits to the conservation and sustainable livelihoods of the town.

Apart from ecotourism a new form of tourism, geotourism, has been a leading trend to develop a more conscious practice of tourist activities by "experiencing the earth's geological features" (Dowling, 2013, p. 61). Geotourism gives the opportunity to protect the geological and landscape heritage by bringing benefits to the local communities and promotes some principles and values that support the responsible behavior of tourist and promoters (Allan, 2015).

According to Ehsan, Leman, and Ara Begum (2013), the increasing amount of scientific information delivered to the general public has triggered the growing interest of tourists in participating in activities of geoconservation. This awareness of tourists 
and service providers has resulted in the development of geotorusim products, which involves certain activities aimed to improve the enviromental protection as well as the quality of life of the communities involved. Dowling (2013, p. 76) mentions: "By presenting income, employment and infra-structural benefits for local regions, geotourism is ofen presented as a mechanism having the potential to offset the local opportunity cost of protected natural areas...". The author also mentions sites that have been declared Protected Natural Areas and which have better capacity to obtain economic benefits derived from the use of landscapes in tourism activities.

In addition, and related to this research, emphasis is placed on the type of management managed by rural communities and which is framed in community management as a form of organization to achieve ecotourism objectives (Adeyinka-Ojo, Khoo-Lattimore, \& Nair, 2014; Blamey, 2001; Buckley, 2009; Idajati, Pamungkas, \& Vely Kukinul, 2016; Tolkach \& King, 2015).

\section{Community ecotourism management}

The control or action taken by residents of ecotourism destinations has been evaluated from different approaches, such as community empowerment (Scheyvens, 1999); collective participation (Ramos \& Prideaux, 2013); community governance (Garrod, 2003; Roseland, 2000); community management (Foucat, 2002), and has recently been associated with community social capital in the field of ecotourism (Jones, 2005; Liu et al., 2014). Such forms of appropriation in the development and consolidation of ecotourism require a collaborative planning between government, community, non-governmental and academic organizations for the proper delimitation of the geographical areas in favor of environmental and socioeconomic benefits (Choi \& Sirakaya, 2006; Marzo-Navarro, Pedraja-Iglesias, \& Vinzón, 2015).

Organizational processes, planning, decision-making, interrelationships and common goals are some features which can be identified as community management (Choi \& Sirakaya, 2006). Some authors such as Garrod (2003) associate community management and ecotourism with good governance. The author states that, from the perspective of the community in relation to governance, the empowerment through statutes, rules and procedures for making decisions arising from the centralized bureaucratic apparatus of government, can hinder the operation of any venture of the community.

Authors like Maldonado (2005) and Ross and Wall (1999) state that under endogenous management and with a certain normative structure, communities can manage, through training and financial support, the protection of the natural environment and use it sustainably through ecotourism.

The participation of the residents in the development of the strategies and plans allows generating abilities between the groups and individuals, helping to direct the results of the different programs (including tourism) in which they participate (Ross \& Wall, 1999). The direction of tourism in the communities has been carried out from two perspectives, the first, refers to the residents of the communities, who can visualize an 
economic benefit through the tourist activity if members of residents' families are part of it. On this same line, there are also disagreements, opposition, and unavailability of residents to participate in the development and operation of tourism because of a negative travel view (Brenner \& San German, 2012; Das \& Chatterjee, 2015).

The second perspective is given by the government in order to protect biodiversityrich natural resources and their relationship with social-cultural schemes, in this way the government avoids the exploitation in all its predatory cycles of the natural and socialcultural environment. The way in which government management in communities derives is through the designation of Natural Protected Areas with a focus on ecotourism; this symbiotic relationship between the community and the natural area initiates different types of tourism practices such as tourism based on nature and community-based tourism (Das \& Chatterjee, 2015; Foucat, 2002; Idajati et al., 2016).

Likewise, the involvement of the community into the management activities strengthens the cultural and natural conservation of destinations, directing the gains to the interior of the communities. The expected benefits in communities are not always economic, and some advantages include the development of infrastructure in public services. Non-economic benefits, however, include developing negotiation skills and people management, gaining experience in managing projects, internal and external networks of mutual aid to strengthen the management of shared resources (Stronza \& Gordillo, 2008).

There are some advantages and disadvantages in ecotourism planning with regard to local participation according to Idajati, Pamungkas, and Vely Kukinul (2016). Garrod (2003) also mentioned as an advantage of ecotourism the increasing empowerment of community's residents that gives them full control over the management of its resources.

On the other hand the disadvantages of ecotourism, as stated by some authors like Cleverdon and Kalisch (2000), Jones (2005), Manyara and Jones (2007), can be very harmful for ecotourism community ventures; these disadvantages can be listed as follows:

- Many people involved in the project;

- The risk of not being carried out by opposition forces and the consequent limitations of access to resources;

- Benefits not always equitably distributed;

- Launching the project can result in a longer period of time due to disputes arising at the date of planning and implementation;

- There may be discrimination and exclusion of the majority groups towards smaller groups . 


\section{Methodology}

This research is defined as a case study with a qualitative approach to discover the perceptions, opinions and points of view of the individuals involved in the phenomenon of implementing eco-tourism as a new economic activity in the community of "El Recreo".

It was the case study as a technique that fits the needs of this work by the stated objective. This delimitation allows a more profound approach and successful processes that give rise to perceived events that are displayed on the means of the cognoscente's subjects (Hancock \& Algozzine, 2011; Merriam, 1998; Stake, 2005; Yin, 1994).

The case study is given in the cooperative "Servitur Rural El Verde Camacho" dedicated to ecotourism, it is located in the community of El Recreo, municipality of Mazatlán Sinaloa. The place holds a population of 579 inhabitants, 282 men, and 297 women according to the National Institute of Statistics and Geography (Instituto Nacional de Estadística y Geografía; INEGI), it also points out that there is a medium degree of marginalization, meaning they have a partial access to health education and jobs. The ecotourism activities are carried out in the sanctuary conservation area, called "Playa Tortuguera El Verde Camacho," near the community of El Recreo. The Sanctuary Camacho is a conservation area of different sea turtle species.

The geographical location, in agreement with the Natural Protected Areas National Commission, is towards the northwest, it borders on Punta Gruesa, near the town of Marmol; the southeast borders the Punta Cerritos; to the west, it is bounded by the Pacific Ocean and to the east there are marshes and the mouth of the river Quelite. This site is located at the coordinates $22^{\circ} 53^{\prime} \mathrm{N}, 106^{\circ} 55^{\prime} \mathrm{W}$. The nesting beach has an area of $25 \mathrm{~km}$ in the coastal perimeter, which corresponds to $31 \%$ of the coastal area of the municipality of Mazatlán, Sinaloa in the northwest of Mexico (CONANP, 2017).

This place is considered the most essential for the reproduction of the Olive Ridley turtle in Sinaloa and it is also a feeding habitat and migration corridor of the hawksbill turtle, black turtle, and leatherback turtle sporadically. Because of its ecosystem importance, the place was declared a RAMSAR site, as well as the "Wetland of International Importance" in 2004 (CONANP, 2017).

The cooperative has 14 members who developed the research and the interviews. This was complemented by other individuals in the community, 25 people who were mostly housewives, non-members of this cooperative but involved to develop its activities of conservation and care of the environment, so they were also considered for the study. Between May and June of 2017, we conducted a semi-structured interview containing specific questions about the objectives of ecotourism identified by different authors with cooperative participants and non-participants.

Literature review was the framework for the structure and the research instrument design, and the primary outcomes were compared with the dimensions defined by Ross and Wall (1999, p. 124), who include wealth generation, environmental education, and involvement of residents associated decision-making with the development and benefits of ecotourism; Stronza and Gordillo (2008), who see in ecotourism the incentive for 
conservation, especially when it integrates positive economic changes and the non-economic as the improvement of self-esteem and community organization. Blamey (2001) who points out that the expectation as to the outcome of eco-tourism should be underpinning the local economy and support for the conservation of the natural and social environment and Garrod (2003), who emphasizes the need to strengthen the community participation in planning and decision-making in ecotourism projects to get tangible benefits from them.

Based on the precepts proposed by the authors mentioned in the previous paragraph, the interview questions were developed. Four dimensions have been taken into account based on the ecotourism objectives proposed by the authors. They are summarized in the provision of environmental education services; conservation of the natural area; development of human capital and socio-economic benefits.

According to these proposed dimensions, items were formulated to discover how the participation of the Government in the creation of the cooperative was performed, which allowed to learn, in a close-up, the legal structure of the cooperative and its relationship between the Government agencies and the residents of the community. These items also explain how these agents were able to formalize and establish the tourism organization.

Another item describes the learning process of the members of the cooperative and this gives important information about the values, skills and know-how about its application in the ecotourism activities.

Questions about the ecotourism principles were also formulated to learn about how conscious the cooperative members are of their role in the conservation of the environment, landscapes and geological features of the area. An item about the perception of the learning activities for the tourist was included in order to address the commitment of the cooperative members to their principles and values supposedly acquired.

Questions about the perceived improvement of the natural area were asked to find out how these ecotourism activities had been beneficial. Likewise, questions about the improvement of their quality of life were formulated trying to clarify the degree of fulfillment of the community expectations from ecotourism as an economic activity.

An interview was also applied to two government representatives responsible for the turtle sanctuary and conservation site. They were in charge of providing accurate information and promoting ecotourism activities in the protected area. Most of the questions were reformulated to find out how much are these ecotourism activities supported by the government.

\section{Results}

\section{Development and structure of ecotourism cooperative}

The cooperative of the Verde Camacho Sanctuary has its beginnings in 1976 when the Natural Protected Area (NPA) was designated for the conservation of sea turtles. This shrine was created through a group of specialists and the National Fisheries Institute 
of Mexico. The development of the cooperative began with a shrimp farm aquaculture project. The members of this project were at that time mostly heads of the Community House, which sought an immediate economic benefit. Most of the inhabitants of this community are fishermen and farmers who usually combine the two activities to obtain the revenues required to survive.

According to the interviewees, in those days the administrator in charge of the NPA warned the community of the danger and environmental damage due to aquaculture in the short time of operation ( 5 years). He advised them not to continue in the same activity and, on the contrary, try another type of entrepreneurship. Nevertheless, the residents decided to start such a cooperative operation. They continued that way until the sons of the collective shrimp farm members came with the idea of the constitution of the eco-tourism cooperative. This new generation of farm members along with CONANP started very soon a training program with conservation practices, courses, and workshops for management of natural resources for its tourist use.

Officially named as Servitur Rural El Verde Camacho S. R. L. (Limited Liability Society), it was registered for tourist activities in the year 2012. The constitution of the cooperative began with 17 people; however, it was reduced to 14 individuals who maintained a gender equity and the age range was between 25 and 40 years.

It is important to note that the highest position was occupied by a woman, Susana, who serves as Cooperative's President; the Treasurer is a man named Efren and vice president Luisa. General Assemblies are celebrated every six months with members of the cooperative. According to the members, the eco-tourism company was built on the values of respect and honesty.

Due to the interests of the group in creating the company, biologist Daniel (the government expert in charge) encouraged members to require training courses to facilitate their integration and overall performance as a company. Some of the courses conducted by the community are with external governmental providers and includes management courses, ecotourism course; group management course; conflict resolution course; natural resource management course; integration courses; and cooking workshop. This in line with the expressed will of Garrod (2003) posed the need to strengthen community participation in planning and decision-making in ecotourism projects to finally get real benefits from them. Workshops management has been organized not only by cooperative members but also by the people responsible for the NPA as well. In this way, the organization participates in the calls for financial resources and support equipment courses for the practice ecotourism in the region.

The equipment that was obtained through the funding of resources were canoes, kayaks, a pickup truck, two ATVs, equipment for the kitchen and classroom for environmental education. The facilities which have been used until today by the cooperative are those occupying the conservation Tortuguero camp, but in the near future, if the cooperative have enough resources, they will move to a different location according to what is mentioned by Susana, the cooperative's leader. 


\section{Perceived benefits of the cooperative according to its members}

Under the experts and CONANP tutelage and continuous preparation, the cooperative started regular operations in 2012 and it is still active today. According to cooperative members this experience has been very satisfying as they have manifested with expressions like these: "we have learned a lot" and "now we see nature in a different way". This manifested satisfaction is a consequence of continuous environmental education, which meets the objectives of eco-tourism stated by Ross and Wall (1999).

An empowerment of women is observed and confirmed by the interviewees; this empowerment is notorious in the cooperative activities assigned to women; according to their statements, women "feel safer" today and less ruled to the decisions of husbands and other male members of the cooperative. This empowerment process eludes one of the dangers of this type of projects mentioned by Jones (2005) on discrimination against vulnerable groups.

Another point cited by Ross and Wall (1999) has to do with the generation of wealth, which so far, has been a goal that has been fulfilled properly according to all the members of the cooperative. In fact, they perceive an improvement in their quality of life with the additional income that allows them access to better food standards, adequate housing, dress, as well as the possibilities of acquiring better education. In this sense, it is convenient to emphasize that the income of the cooperative is distributed equally among all its members without creating a difference between those who hold managerial positions and those who have the operational positions.

According to the biologists responsible for the sanctuary, the tourist activity of the place conforms to the parameters required by the site of conservation regarding carrying capacity, so the number of tourists that can visit the area is limited to a maximum of 22 people per day. The members commented that sometimes, in the high season, up to three groups of 14 people can be received on different days without exceeding the maximum amount allowed in the daytime. The activities offered are kayaks, canoes or ATV rides. These activities are only for observation of local flora and fauna. Tourists are not allowed to wander on their own, thereby limiting the impact on the ecosystem.

Education for sustainability by Ross and Wall (1999) is presented in several levels or areas; according to the interviewees, there is a continuous training for the permanent members of the cooperative who transmitted it to their families and the community in general. Also, they provide talks and presentations to visitors from educational institutes with the objective of promoting environmental stewardship. Finally, this education is also directed to visitors or tourists from the site with whom some awareness work is performed by tour guides operating in Mazatlán. Those actions for visitors generate attitudes of awareness about what they will find out and do in the place.

The process of learning for women has a novel perspective. This new process is their opportunity for improvement as they do not want to be only housewives. In this way, they decided to integrate to the cooperative despite being married and having children who depend on them. Due to sociocultural structures that still dominate rural areas (especially in developing countries like Mexico), this project has been a new challenge 
to their condition of women; women who want more participation and more independence from a manly society.

The knowledge that they have acquired through environmental education makes them realize the importance of natural resources care because they see in it a condition of social welfare, and as it was referred before, they had less information, so they were less likely to care about the environment.

Hence, the perspective of the members concerning the natural environment has changed to reduce contamination of waste in their daily lives. In addition, the government encourages these attitudes by giving a small economic reward to a group of about 20 to 25 women and children who clean the beach on a regular basis. The cooperative became responsible for managing the cleaning of the beach and in this sense, men are dedicated to their main economic activities as fishermen and farmers, and women and children do the recollection of garbage on the beach.

The last point of the scheme of Ross and Wall (1999) has to do with the direct participation of the community in preservation activities. This was confirmed with the respondents who handle a certain predisposition to support the operations of the cooperative regarding the cleanliness of beaches that are regularly performed, as well as cleaning all the way from access to their community to provide a better image and protect the ecosystem. It should be observed that the activities of conservation and care of the beach on a regular basis have contributed to the fact that the beach was certified as a "Clean Beach" by CONAGUA (Comisión Nacional de Agua; in English Water National Comission), an office in charge of the preservation of water resources of the Mexican Government.

The tourism quality is another aspect pointed out by Ross and Wall (1999). It is perceived in a very positive way by the members of the cooperative because, according to the comments that visitors leave in the form of an opinion survey, it makes them assume that they provide a service that meets their expectations. It should be mentioned that, due to the arrival of foreign tourists, the use of the English language is necessary, which represents a disadvantage for cooperators, who depend on the tourist guides that accompany them to provide information concerning the site and its activities. The members observed that while English courses were given to them, their progress was limited by the frequency of such courses, as well as other issues like time and work, which had prevented them from developing the skills to use this much-needed tool for their ecotourism activities.

The interviewed people that do not belong to the cooperative expressed their willingness to participate, although there is no direct or usual remuneration for their collaboration. This group of 25 people, mostly housewives, was very conscious of the needs of the cooperative and the benefits to be obtained from its activities reflected in an improvement in the conditions of life for all in the community in which most of them also share direct blood ties.

Finally, some of the main results of the interviews are presented in Table 1 below in order to facilitate their understanding. 
Table 1 Interviews main results

\begin{tabular}{|l|l|}
\hline Categories & Results \\
\hline $\begin{array}{l}\text { Government participation in } \\
\text { the ecotourist cooperative } \\
\text { creation }\end{array}$ & $\begin{array}{l}\text { A strong impulse for ecotourism activities among the community } \\
\text { inhabitants. It provides all the legal support for the cooperative } \\
\text { foundation and the transfer of knowledge and values of ecotourism. }\end{array}$ \\
\hline $\begin{array}{l}\text { Consciousness of } \\
\text { ecotourism principles }\end{array}$ & $\begin{array}{l}\text { Most of the interviewees showed a strong commitment to the } \\
\text { ecotourism principles, especially among the leaders of the } \\
\text { cooperative. A new set of values for sustainability is identified in the } \\
\text { majority of cooperative members. Culture is changing. }\end{array}$ \\
\hline $\begin{array}{l}\text { Acquired knowledge and } \\
\text { skills for ecotourism }\end{array}$ & $\begin{array}{l}\text { All interviewees agree about the quantity and quality of capacitation } \\
\text { received; from managerial process to environmental conservation, } \\
\text { also including the specific knowledge and skills for tourist activities. }\end{array}$ \\
\hline $\begin{array}{l}\text { Perception of their role in } \\
\text { environmental conservation }\end{array}$ & $\begin{array}{l}\text { They perceived themselves as an important element for the } \\
\text { conservation of the ecological balance of the area. They are now } \\
\text { organized to keep the area as clean and pristine as possible. }\end{array}$ \\
\hline $\begin{array}{l}\text { Dissemination of ecological } \\
\text { knowledge }\end{array}$ & $\begin{array}{l}\text { The members of the cooperative give some lessons and chats about } \\
\text { the importance of the conservation activities to the visitors, some of } \\
\text { them are students of different school levels. }\end{array}$ \\
\hline $\begin{array}{l}\text { Improvement of the } \\
\text { environment and } \\
\text { landscapes }\end{array}$ & $\begin{array}{l}\text { The carrying capacity of the place is respected, and the impact of } \\
\text { tourism activities is minimized. Guidance to the visitors during the } \\
\text { time they spend in the sanctuary. Cleaning and surveillance activities } \\
\text { are performed to keep the area in its natural state. }\end{array}$ \\
\hline $\begin{array}{l}\text { Improvement of quality } \\
\text { of life in the community } \\
\text { members }\end{array}$ & $\begin{array}{l}\text { Interviewees stated that with the cooperative incomes they had } \\
\text { now better food standards, adequate housing, dress, as well as } \\
\text { the possibilities of acquiring better education. Still, some of the } \\
\text { community services as health, water supply, sewer system, garbage } \\
\text { collection and education need improvement. A strong process } \\
\text { of women empowerment is observed; genders equality is finally } \\
\text { reached in the cooperative. }\end{array}$ \\
\hline
\end{tabular}

Source: own processing

\section{Discussion}

What was expected according to the literature review and what was observed in the destination brings to discussion what Tsaur et al. (2006), Wood (2002), and Dowling (2013) state for ecotourism as a tool for sustainable development in the community [...] that are rich in natural and geographical elements [...]. Being El Verde Camacho a natural protected area, it gathered a great diversity of unique flora and fauna, including distinctive geography and landscapes. It can be said that the place is perfect for the development of ecotourism or geotourism activities.

El Verde Camacho fulfills an important role in the conservation of some endangered species like sea turtles and three different species of mangrove. That is the reason why 
the correct management of the resources is of great importance for authorities, as well as for the inhabitants of the place. This community now is aware of the conservation of natural resources for environmental benefit and the strengthening of economic and socio-cultural factors for the development of sustainable tourism (Tsaur et al., 2006; Wood, 2002). This conservation of natural resources is supported by sustainable practices such as garbage collection, visitor control per day, total control of hiking activities, or prevention of monitoring of fauna extraction.

Citing Hetzer (1965) and his four premises regarding ecotourism, it was found out that three of them were met, including the minimization of environmental impacts by establishing a load capacity in the Sanctuary; the respect of local cultures for their uses and customs; the maximization of benefits for local people that has been given directly and indirectly to the community, remaining the improvements in public services of the community as a pending task. It also fulfills some premises of Stronza and Gordillo (2008) about the economic advantages derived from ecotourism.

In relation to the previous paragraph, one of the provided premises that geotourism manages (Dowling, 2013) is the preservation of the natural landscape. According to the observed in the field, the elements that make up the natural landscape in the Sanctuary remain in an optimal state. That optimal state can be explained by the regulation of access policies and the conservation and improvement of the biotic and abiotic resources.

Another important aspect of the development of ecotourism and geotourism activities pointed by Ross and Wall (1999), Ehsan et al. (2013), and Allan (2015) is education and the transposing of ecological values. It was observed the behavior and enthusiasm of the members of the tourism cooperative were generated through constant training in the management of natural resources. This education is not only for the cooperative members but for tourists who arrive at the Sanctuary with little knowledge and leave very satisfied with the information received and the environmental awareness activities that are offered in the Sanctuary.

Regarding the context of the community management, structured organizational processes were observed in planning and decision making, which were developed through the trainings that were initially provided with the support of government organizations and those in charge of the NPA. The aforementioned agrees with the premises indicated and commented on in the framework of this investigation by Garrod (2003), Choi and Sirakaya (2006). It is important to address the empowerment generated by members of the cooperative, especially women, who now play the main role in management. Something important that the members mentioned is the strengthening of ethical, moral and trust values that in conjunction with the endogenous and learned management processes indicate how the economic and non-economic benefits were specified. This has been also confirmed by Stronza and Gordillo (2008), Garrod (2003) and Idajati et al. (2016). A scheme of the developing process of the cooperative is presented in Figure 1 below in order to clearly understand how the main hypothesis of this study was proven true: 
Figure 1 Developing process of the ecotourism cooperative "Servitur Rural El Verde Camacho"

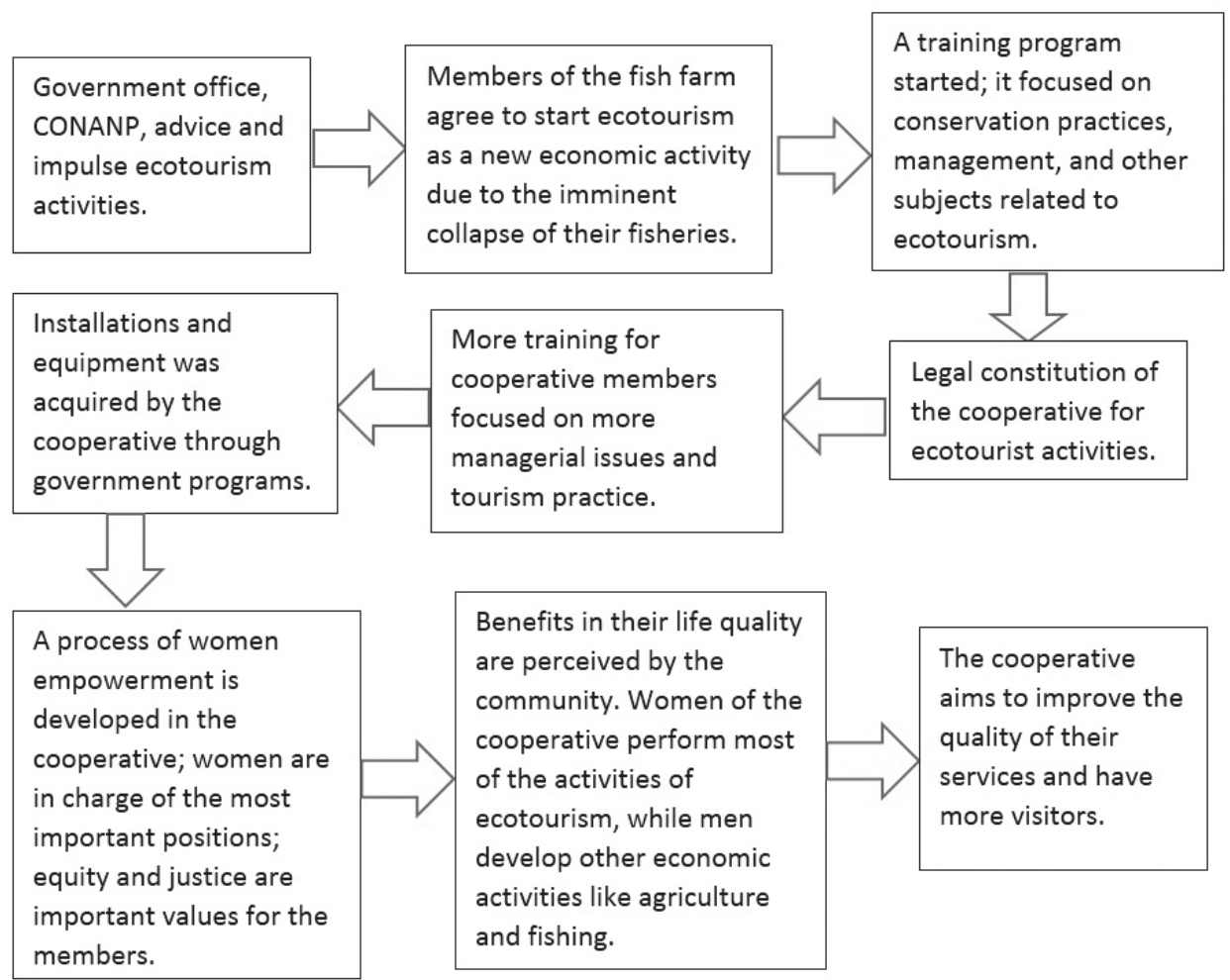

Source: own processing

\section{Conclusion}

This cooperative is a clear example of how the link between government agencies and the experts representing these dependencies can create a synergy with the community in the development, operation, and integration of a rural ecotourism endeavor. Some similar previous studies that have been documented in various contexts had different outcomes and mentioned that there are examples of cooperatives which generate exclusion to other members, as well as the unequal distribution of economic benefits and training. However, El Verde Camacho case is a success story; it shows the integration of the people for a common purpose.

The wish of several community residents to create the cooperative would not have been a reality without the support of the people responsible for the PNA El Verde Camacho. The advice and support that came from these government experts was a key element that resulted in the legal Constitution of the cooperative. This cooperative venture was also supported by CONANP, that contributed with some important tools to guarantee its permanence like constant training and some equipment that allowed the 
cooperative to give the service and awareness chats of environmental conservation to visitors. Other actions that ensure the success of this ecotourist venture are carried out by the cooperative members such as the periodical cleaning of the beach where different species turtles arrive to spawn.

In this way, it can be concluded that government agencies such as CONANP, supporting eco-tourism projects in protected natural areas, is triggering community ecotourism businesses in Mexico. In this particular case, some aspects are worth an attention, like the continuous education and constant training to the cooperative members. Those actions, along with the experience gained by the cooperative, has proven to be a crucial factor for the permanence and success of this venture in the long term.

It is important to point out the clear limitations of this study that is not intended to create a new and revolutionary theory but, in some manner, to test the already existing hypothesis. This case study can be a clear example of known recipes for a successful ecotourist ventures and also as the beginning of new research focus on some different areas like women empowerment in rural tourist context, organizational culture in ecotourist ventures and the role of government in the success of this kind of activities.

\section{Acknowledgment}

The authors want to thank the direct participation of the members of the cooperative El Verde Camacho, as well as the biologist Daniel, who gave us the necessary trust and access to the community to take this experience of ecotourism management (geotourism) to the academic level.

\section{References}

Adeyinka-Ojo, S. F., Khoo-Lattimore, C., \& Nair, V. (2014). A Framework for Rural Tourism Destination Management and Marketing Organisations. Procedia - Social and Behavioral Sciences, 144, 151-163. DOI: 10.1016/j.sbspro.2014.07.284.

Allan, M. (2015). Geotourism: an opportunity to enhance geoethics and boost geoheritage appreciation. Geological Society, London, Special Publications, 419(1), 25-29.

Blamey, R. K. (2001). Principles of ecotourism. The encyclopedia of ecotourism, 5-22.

Boyd, S. W., \& Butler, R. W. (1996). Managing ecotourism: an opportunity spectrum approach. Tourism Management, 17(8), 557-566. DOI: 10.1016/S0261-5177(96)00076-3.

Brenner, L., \& San German, S. (2012). Gobernanza local para el "ecoturismo" en la Reserva de la Biosfera Mariposa Monarca, México. Alteridades, 22(44), 131-146.

Buckley, R. (2009). Evaluating the net effects of ecotourism on the environment: a framework, first assessment, and future research. Journal of Sustainable Tourism, 17(6), 643-672. DOI: 10.1080/09669580902999188.

Choi, H. S. C., \& Sirakaya, E. (2006). Sustainability indicators for managing community tourism. Tourism Management, 27(6), 1274-1289. DOI: 10.1016/j.tourman.2005.05.018.

Cleverdon, R., \& Kalisch, A. (2000). Fairtrade in tourism. The International Journal of Tourism Research, 2(3), 171. 
CONANP, Comision Naciona de Areas Naturales Protegidas. (2017). Santuario Tortuguero El Verde Camacho. Retrieved from http://elverdecamacho.conanp.gob.mx/stvc/.

Das, M., \& Chatterjee, B. (2015). Ecotourism: A panacea or a predicament? Tourism Management Perspectives, 14(April), 3-16. DOI: 10.1016/j.tmp.2015.01.002.

Dowling, R. K. (2013). Global geotourism-an emerging form of sustainable tourism. Czech Journal of Tourism, 2(2), 59-79. DOI: 10.2478/cjot-2013-0004.

Ehsan, S., Leman, M. S., \& Ara Begum, R. (2013). Geotourism: A tool for sustainable development of geoheritage resources. Advanced Materials Research, 622, 1711-1715.

Foucat, V. S. A. (2002). Community-based ecotourism management moving towards sustainability, in Ventanilla, Oaxaca, Mexico. Ocean E Coastal Management, 45, 511-529.

Garrod, B. (2003). Local Participation in the Planning and Management of Ecotourism: A Revised Model Approach. Journal of Ecotourism, 2(1), 33-53. DOI: 10.1080/14724040308668132.

Hancock, D. R., \& Algozzine, B. (2011). Doing Case Study Research: A Practical Guide for Beginning Researchers. New York/London: Teachers College Press.

Hetzer, N. D. (1965). Environment, Tourism, Culture. UNNS, Reported Ecosphere (pp 1-3). UNNS.

Idajati, H., Pamungkas, A., \& Vely Kukinul, S. (2016). The Level of Participation in Mangrove Ecotourism Development, Wonorejo Surabaya. Procedia - Social and Behavioral Sciences, 227, 515-520. DOI: 10.1016/j.sbspro.2016.06.109.

Jones, S. (2005). Community-based ecotourism: The significance of social capital. Annals of Tourism Research, 32(2), 303-324. DOI: 10.1016/j.annals.2004.06.007.

Kiss, A. (2004). Is community-based ecotourism a good use of biodiversity conservation funds? Trends in Ecology Ẽ Evolution, 19(5), 3-8. DOI: 10.1016/j.tree.2004.03.010.

Liu, J., Qu, H., Huang, D., Chen, G., Yue, X., Zhao, X., \& Liang, Z. (2014). The role of social capital in encouraging residents' pro-environmental behaviors in community-based ecotourism. Tourism Management, 41, 190-201. DOI: 10.1016/j.tourman.2013.08.016.

Maldonado, C. (2005). Pautas metodológicas para el análisis de experiencias de turismo comunitario. Retrieved from http://campesinoacampesino.com/biblioteca/ECOBONA_0267.pdf.

Manyara, G., \& Jones, E. (2007). Community-based tourism enterprises development in Kenya: An exploration of their potential as avenues of poverty reduction. Journal of Sustainable Tourism, 15(6), 628-644. DOI: 10.2167/jost723.0.

Marzo-Navarro M., Pedraja-Iglesias M., \& Vinzón L. (2015) Sustainability indicators of rural tourism from the perspective of the residents. Tourism Geographies, 17(4), 586-602. DOI: 10.1080/14616688.2015.1062909.

Merriam, S. B. (1998). Case Studies as Qualitative Research. Case study research in education: a qualitative approach. San Francisco: Jossey-Bass Publishers.

Ramos, A. M., \& Prideaux, B. (2013). Indigenous ecotourism in the Mayan rainforest of Palenque: empowerment issues in sustainable development. Journal of Sustainable Tourism, 22(3), 461-479. DOI: $10.1080 / 09669582.2013 .828730$.

Roseland, M. (2000). Sustainable community development: integrating environmental, economic, and social objectives. Progress in Planning, 54(2), 73-132. DOI: 10.1016/S0305-9006(00)000039.

Ross, S., \& Wall, G. (1999). Ecotourism: Towards congruence between theory and practice. Tourism Management, 20(1), 123-132. DOI: 10.1016/S0261-5177(98)00098-3.

Scheyvens, R. (1999). Ecotourism and the Empowerment of Local Communities Ecotourism and the empowerment of local communities. Tourism Management, 20, 245-249. DOI: 10.1016/ S0261-5177(98)00069-7. 
Stake, E. R. (2005). Qualitative case studies. In N. K. Denzin \& Y. S. Lincoln (Eds.), The Sage handbook of qualitative research (pp. 443-466). Thousand Oaks/London/New Delhi: Sage Publications.

Stronza, A., \& Gordillo, J. (2008). Community Views of Ecotourism. Annals of Tourism Research, 35(2), 448-468. DOI: 10.1016/j.annals.2008.01.002.

Tolkach, D., \& King, B. (2015). Strengthening Community-Base Tourism in a new resourcebase island nation: Why and how? Tourism Management, 15, 386-398. DOI: 10.1016/j.tourman.2014.12.013.

Tsaur, S., Lin, Y., \& Lin, J. (2006). Evaluating ecotourism sustainability from the integrated perspective of resource, community, and tourism. Tourism Management, 27, 640-653. DOI: 10.1016/j. tourman.2005.02.006.

Weaver, D. B., \& Lawton, L. J. (2007). Twenty years on: The state of contemporary ecotourism research. Tourism Management, 28(5), 1168-1179.

Wood, M. E. (2002). Ecotourism: Principles, practices and policies for sustainability. Nairobi, Kenya: UNEP.

Yin, R. K. (1994). Case study research: Design and methods. Thousand Oaks/London/New Delhi: Sage Publications. 